\title{
Differences in fruit growth and ripening of early-, mid- and late-season maturing Japanese plum cultivars
}

\author{
Ahmad Sattar Khan ${ }^{1,2, \star}$ \\ 1 Institute of Horticultural Sciences, University of Agriculture, Faisalabad, Pakistan \\ 2 Curtin Horticulture Research Laboratory, Faculty of Science and Engineering, Curtin University, Perth, WA, Australia
}

Received 18 June 2015 - Accepted 15 February 2016

\begin{abstract}
Introduction. Plum cultivars exhibit differences in their fruit quality; however, very little is known about the changes in fruit growth and quality of plum cultivars maturing in different seasons. This study was conducted to contribute to a better understanding of the fruit growth and ripening behavior of Japanese plum (Prunus silicina Lindl.) varieties according to their maturing season. Materials and methods. Three Japanese plum cultivars were studied: early- ['Black Amber' (BA)], mid- ['Amber Jewel' (AJ)] and late-season ['Angelino' (AG)] maturing. The increase in fruit weight and diameter was determined from days after full bloom (DAFB) to harvest, whilst changes in fruit pulp, skin and seed dry weights, fruit firmness, soluble solid contents (SSC), and titratable acidity (TA) were studied during days after stone hardening (DASH). Ethylene production, respiration rate, activities of 1-aminocyclopropane-1carboxylic acid synthase (ACS) and 1-aminocyclopropane-1-carboxylic acid oxidase (ACO) enzymes, fruit firmness, fruit color, SSC, TA, ascorbic acid, total antioxidant and carotenoid contents were determined at alternate days during fruit ripening. Results and discussion. All plum cultivars exhibited three distinct phases of fruit growth and development in the DAFB. The AG fruit exhibited the longest duration of phase-III, about 64 days and 12 days more, as compared with BA and AJ fruits, respectively. Fruit skin dry weight (\%) was higher for AG fruit, whilst, AJ and BA fruits exhibited the highest increase in seed and pulp dry weight (\%) during DASH. The BA and AJ fruits showed climacteric fruit ripening with a sharp rise in ACS and ACO enzymes; whereas AG fruit showed suppressed climacteric ripening. During the fruit ripening period AG fruit remained more firm with higher SSC, and SCC:TA ratio as compared with BA and AJ fruits. The level of ascorbic acid $\left(24.8 \mathrm{mg} 100 \mathrm{~g}^{-1}\right)$ was higher in AG fruit. Whilst, total

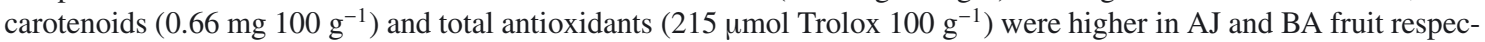
tively. Conclusion. The physico-chemical changes during fruit ripening vary with cultivar and are associated with the level of endogenous ethylene production. Japanese plum cultivars exhibit varying levels of SSC, SSC:TA ratio, levels of individual and total antioxidants of their ripe fruits.
\end{abstract}

Keywords: Australia / plum / Prunus silicina / fruit quality / fruit maturity / phenolics / antioxidant activity / ethylene biosynthesis

Résumé - Différences de croissance et de mûrissement des fruits de cultivars de prunier japonais précoce, de mi-saison et tardif. Introduction. Les variétés de prunier présentent des fruits aux qualités distinctes; cependant, on sait très peu de chose sur les changements qui s'opèrent au cours de la croissance des fruits et de l'élaboration de la qualité entre les variétés de précocités différentes. Cette étude contribue à mieux comprendre le comportement variétal lors de la croissance et le mûrissement des fruits en fonction de la précocité du cultivar de prunier japonais (Prunus silicina Lindl.). Matériel et méthodes. Trois variétés de prunes ont été testées : précoce [«Black Amber»(BA)], de mi-saison [«Amber Jewel» (AJ)] et tardive [« Angelino » (AG)]. Les augmentations du poids et du diamètre des fruits ont été déterminés depuis la date de pleine floraison (DAFB) jusqu'à la récolte, tandis que les changements suivants ont été étudiés dans les jours qui ont suivi le durcissement du noyau (DASH) : poids sec de la pulpe, de la peau et du noyau des fruits, fermeté des fruits, teneur en matières solubles (SSC) et acidité (TA). La production d'éthylène, le taux de respiration, les activités enzymatiques de la 1-aminocyclopropane-1-carboxylique synthase (ACS) et de l'acide 1-aminocyclopropane-1-carboxylique oxydase (ACO), la fermeté des fruits, la couleur des fruits, SSC, TA, l'acide ascorbique, l'activité anti-oxydante totale et le contenu en caroténoïdes ont été déterminés tous les deux jours durant la période de mûrissement.

^ Corresponding author: ahmad_khan157@yahoo.com 


\begin{abstract}
Résultats et discussion. Tous les cultivars de prunier ont présenté trois phases distinctes de croissance et du développement des fruits sur DAFB. Les fruits d'AG présentaient la plus longue durée de la phase-III, environ 64 jours et 12 jours de plus, par rapport aux fruits de BA et d'AJ, respectivement. Le poids sec (\%) de la peau des fruits était plus élevé chez AG, tandis que, chez AJ et BA, les poids secs du noyau et de la chair (\%) des fruits présentaient la plus forte augmentation sur DASH. Les fruits de BA et d'AJ ont exprimé un mûrissement de fruit climactérique avec une forte augmentation des enzymes ACS et ACO; alors que les fruits d'AG ont montré une suppression du mûrissement climatérique. Au cours de la période de mûrissement, les fruits d'AG sont restés plus fermes avec un taux de matières solubles (SSC) plus élevé, et un rapport SSC:TA comparable à ceux des fruits de BA et d'AJ. La teneur en acide ascorbique $\left(24,8 \mathrm{mg} 100 \mathrm{~g}^{-1}\right)$ était plus élevée chez les fruits d'AG. Les teneurs en caroténoïdes totaux $(0,66 \mathrm{mg}$ $\left.100 \mathrm{~g}^{-1}\right)$ et en anti-oxydants totaux $\left(215 \mu \mathrm{mol}\right.$ Trolox $\left.100 \mathrm{~g}^{-1}\right)$ étaient eux, plus élevées dans les fruits d'AJ et de BA, respectivement. Conclusion. Les modifications physico-chimiques lors du mûrissement des fruits varient avec le cultivar et sont associées à des taux de production d'éthylène endogène. Les cultivars de prunier japonais présentent des niveaux variables de matières solubles, du rapport SSC:TA, et d'antioxydants individuels et totaux de leurs fruits mûrs.
\end{abstract}

Mots clés : Australie / prunier / Prunus silicina / qualité du fruit / mûrissement / composés phénoliques / activité anti-oxydante / biosynthèse d'éthylène

\section{Introduction}

The plum is a nutritious stone fruit grown in cooler subtropical to temperate climates around the world. At present, among different plum producing countries, the USA is the leading country in the world having plum exports with value of about 196.4 million US\$ [1]. As compare to the world, the Australian plum industry is very small. However, in the Australian Horticulture Industry plum production occupies a prominent position among the stone fruits with great potential for export. During the years 2011-2012 out of 34,000 t of plum production in Australia, about 21,300 t, with a value of 18.2 million AUS\$ were exported. Western Australia (WA) contributes about 53\% of Australian plum export [2]. Western Australia has a temperate Mediterranean climate, suitable soil, quality irrigation water to produce high quality plum fruit [3].

Japanese plum (Prunus silicina Lindl.) and European plum (Prunus domestica L.) belong to the sub-family Prunoidae of the family Rosaceae. Differences in tree structure and growth habit, fruit growth and development, fruit shape and quality parameters are not only present within these two species but also between various cultivars [4]. Fruit growth pattern in Japanese and European plum is double sigmoid [5], characterised by a initial period of rapid cell division and growth [6], stone hardening followed by a rapid increase in fruit growth in term of fruit weight and size [7]. Sugars and soluble solids accumulate during the last stage of fruit growth and development. Organic acid first increases and then gradually decreases with fruit maturity $[5,8]$. During the early stage of plum growth the phenolic constituents of fruit remain high and then decrease with advancement in fruit maturity and finally at harvest exhibit very little change [9]. At the final stage of fruit maturity, fruit growth ceases, chlorophyll content in skin decreases and levels of total carotenoids increases [10].

Optimum stage of fruit maturity at harvest depends mainly on the intended use of the fruit and type of cultivar [11]. The sequence of changes in fruit color also occurs as the fruit become mature, but vary with the cultivar and climatic conditions. Soluble solid contents (SSC) increases with the advancement of maturity with a corresponding decrease in the titratable acidity (TA) [12]. The maturity indices used for plum fruit include changes in fruit skin color, firmness, juice content, SSC and TA $[13,14]$.

Like most of the stone fruits, the plum has a climactericripening pattern, in which ethylene triggers the ripening and senescence process with reduction in the fruit weight, firmness, texture, aroma production and occurrence of off-flavour and decay [15]. Commercially, Japanese and European plum are harvested at a mature stage prior to ripening, During ripening physiological changes occurs in respiration rate, ethylene production, fruit firmness, and other physico-chemical properties which brings the mature fruit from a hard and sour state with unacceptable texture, taste and flavour to more favourable state for consumption. An understanding of physiological changes in Japanese plum fruit during growth and ripening will help us to harvest and consume fruit with the best eating quality [16]. Therefore, in this study an attempt was made to understand how differently maturing Japanese plum cultivars behave during fruit growth and ripening stages.

\section{Materials and methods}

\subsection{Plant materials}

Differently maturing Japanese plum (Prunus salicina Lindl.) cultivars which include 'Black Amber' (Black Amber, early-season), 'Amber Jewel' (Amber Jewel, mid-season) and 'Angelino' (Angelino, late-season) grown at Casuarina Valley Orchards, Perth Hills ( $31^{\circ} 57^{\prime}$ S; $115^{\circ} 50^{\prime}$ E), WA, Australia were used in this experiment. All these cultivars were grafted on 'Myrobalan' rootstock. BA and AJ trees were cultivated at south to north row direction, whereas, AG trees were planted in a south-easterly direction. All trees were trained as "palmette" system with $2.5 \mathrm{~m}$ and $4.25 \mathrm{~m}$ within the trees and rows respectively. To study the changes in fresh fruit size and weight sampling was carried out at 14 days intervals started on 16 days after full bloom (DAFB) for BA plum and on 17 DAFB for $\mathrm{AG}$ and $\mathrm{AJ}$ plum fruits, respectively, until fruit reached harvest maturity. Absolute growth rate was determined as an average per day increase in weight or diameter of the fruit. Changes 
Table I. Maturity indices for early-, mid- and late-maturing Japanese plum cultivars at commercial harvest (data are mean values \pm standard deviation, $n=24$ ( 8 fruits $\times 3$ replications) for fruit firmness and $n=3$ replicates for the other parameters).

\begin{tabular}{lcccc}
\hline Cultivars & $\begin{array}{c}\text { Ethylene } \\
\left(\mu \mathrm{mol} \mathrm{kg} \mathrm{h}^{-1}\right)\end{array}$ & $\begin{array}{c}\text { Respiration } \\
\left(\mathrm{mmol} \mathrm{CO}_{2} \mathrm{~kg}^{-1} \mathrm{~h}^{-1}\right)\end{array}$ & $\begin{array}{c}\text { Firmness } \\
(\mathrm{N})\end{array}$ & $\begin{array}{c}\text { Soluble solid contents } \\
\left({ }^{\circ} \mathrm{Brix}\right)\end{array}$ \\
\hline Black Amber (BA) & $0.001 \pm 0.001$ & $0.65 \pm 0.04$ & $32.60 \pm 0.65$ & $10.2 \pm 0.2$ \\
Amber Jewel (AJ) & nd & $0.52 \pm 0.31$ & $28.30 \pm 0.92$ & $12.5 \pm 0.3$ \\
Angelino (AG) & nd & $0.26 \pm 0.03$ & $34.20 \pm 0.81$ & $14.2 \pm 0.2$ \\
\hline
\end{tabular}

nd $=$ not detected.

in the fruit pulp, skin and seed dry weight; fruit firmness; fruit SSC, and TA were determined in each cultivar at 14 days intervals started on 14 days after stone hardening (DASH), till fruit reached to harvest maturity. Fruit of all three cultivars were harvested at commercial mature stages (table I), on 14 January, 7 February and 18 March 2005, respectively. Respiration rates and ethylene production from plum fruit were recorded daily during the ripening; whereas, 1-aminocyclopropane-1- carboxyl acid (ACC) contents, activities of the ACO and ACS enzymes, and different quality parameters such as fruit firmness, SSC, TA, SSC:TA ratio, chromaticity values $\left(L^{*}, a^{*}\right.$ and $\left.b^{*}\right)$, Chroma $\left(C^{*}\right)$, hue angle $\left(h^{\circ}\right)$, ascorbic acid, antioxidants and carotenoids were determined on alternate days till fruit was fully ripe. For each parameter under study, unless otherwise specified, six fruits were used as a sampling unit replicated thrice.

\subsection{Determination of fruit growth and development}

Data on fruit growth was recorded by measuring fruit diameter $(\mathrm{mm})$, fruit weight $(\mathrm{g})$, fresh and dry seed weight $(\%)$, pulp weight $(\%)$ and skin weight $(\%)$ of 15 individual fruits replicated three times.

\subsection{Ethylene production and respiration rate}

Ethylene production ( $\mu \mathrm{mol} \mathrm{kg}^{-1} \mathrm{~h}^{-1}$ ) was determined during plum fruit ripening using gas chromatograph $(6890 \mathrm{~N}$, Agilent Technologies, CA, USA) as outlined by Khan and Singh [17]; whereas, respiration rates $\left(\mathrm{mmol} \mathrm{CO} \mathrm{kg}^{-1} \mathrm{~h}^{-1}\right)$ were determined using infrared gas analyser (Servomex Ltd., East Sussex, UK) as described by Khan and Singh [18].

\subsection{Activities of ACS and ACO enzymes and $A C C$ content}

In the pulp tissues of plum fruit samples, activities of ACS (pmol ACC mg protein ${ }^{-1} \mathrm{~h}^{-1}$ ) and ACO (nmol $\mathrm{C}_{2} \mathrm{H}_{4} \mathrm{mg}$ protein ${ }^{-1} \mathrm{~h}^{-1}$ ) enzymes and ACC contents $\left(\mathrm{pmol} \mathrm{\textrm {g } ^ { - 1 }}\right.$ ) were estimated as described by Khan and Singh [17]. For determination of ACS enzymes, samples $(10 \mathrm{~g})$ containing $5 \mathrm{~mL} 0.5 \mathrm{M}$ K-phosphate buffer $(8.5 \mathrm{pH})$, $5 \mu M$ pyridoxal-phosphate and $5 \mathrm{~m} M$ dithiothreitol, $5 \%$ polyvinylpyrrolidone (PVP) and $400 \mathrm{mg}$ white quartz sand (Sigma-Aldrich, Australia) were first homogenized and then centrifuged at $14,000 \times g$ for $30 \mathrm{~min}$. Supernatant $(2 \mathrm{~mL})$ reacted with $1 \mathrm{~mL}$ of $500 \mu M$ s-adenosyl methionine (SAM), $0.1 \mathrm{~mL}$ of $50 \mathrm{mM} \mathrm{HgCl}, 0.3 \mathrm{~mL}$ of $5 \% \mathrm{NaOCl}$, and saturated $\mathrm{NaOH}[2: 1(\mathrm{v} / \mathrm{v})]$ was used to detect ethylene production through a gas chromatograph through a series of steps as outlined in detail by Khan and Singh [17]. Activity of ACO enzyme was determined by homogenizing fruit pulp tissues $(2 \mathrm{~g})$ with $5 \mathrm{~mL} 0.1 \mathrm{M}$ Tris- $\mathrm{HCl}(\mathrm{pH} 7.2), 10 \%$ (w/v) glycerol, $30 \mathrm{~m} M$ sodium ascorbate, $5 \%$ PVP using $200 \mathrm{mg}$ white quartz sand. The homogenization samples were then centrifuged at $14,000 \times g$ for $30 \mathrm{~min}$ and supernatant $(1.8 \mathrm{~mL})$ was used to react with $0.1 \mathrm{~mL}$ of $40 \mathrm{mM}$ ACC and $0.1 \mathrm{~mL}$ of $1 \mathrm{~m} M$ $\mathrm{FeSO}_{4}$ in properly sealed glass tubes. After incubation at $30^{\circ} \mathrm{C}$ for $1 \mathrm{~h}, 1 \mathrm{~mL}$ gas samples taken from the tubes were used to estimate ethylene production through a gas chromatograph as previously detailed [17]. ACC contents were assessed in fruit pulp tissues $(5 \mathrm{~g}$ ) homogenized [with $10 \mathrm{~mL}$ distilled water using white quartz sand at $2 \pm 1{ }^{\circ} \mathrm{C}$ ] and centrifuged at $10,000 \times g$ for $20 \mathrm{~min}$ at $4{ }^{\circ} \mathrm{C}$. Supernatant $(0.5 \mathrm{~mL})$ was reacted with $0.1 \mathrm{~mL}$ of $50 \mathrm{mM} \mathrm{HgCl} 2$ either with or without $0.1 \mathrm{~mL}$ of $100 \mu M \mathrm{ACC}$ in sealed test tubes in a series of steps as outlined earlier [17].

\subsection{Protein determination}

The protein contents $\left(\mathrm{mg} \mathrm{g}^{-1} \mathrm{FW}\right)$ in pulp tissues were estimated by using bovine serum albumin as a standard as reported by Bradford [19].

\subsection{Fruit firmness}

A thin slice of fruit skin tissues was removed from two sides of each plum fruit sample and firmness was determined as newtons (N) using an electronic firmness tester (Model EPT-1, Kelowna, BC, Canada) fitted with an 8-mm tip.

\subsection{Soluble solid content and titratable acidity}

Soluble solid contents (SSC, in ${ }^{\circ}$ Brix) of filtered plum fruit juice were determined with an Atago hand held refractometer (Atago PR 101, Tokyo, Japan). Titratable acidity (TA, in \% malic acid) of same juice samples was recorded by titrating it against $0.1 \mathrm{~N} \mathrm{NaOH}$ at $\mathrm{pH} 8.2$ using phenolphthalein as an indicator to a persistent pink color end point. SSC: TA ratio was calculated by dividing SSC with corresponding TA values. 


\subsection{Fruit color}

Changes in fruit skin color characteristics such as $L^{*}, a^{*}$, and $b^{*}$ were estimated using Hunterlab ColorFlex (Hunter Associates Inc., Reston, VA) having $15 \mathrm{~mm}$ head by taking two measurements from opposite sides of each fruit. The values of chroma $\left(C^{*}\right)$ and hue angle $\left(h^{\circ}\right)$ were further calculated from chromaticity values $a^{*}$ and $b^{*}$ by using the method reported earlier by McGuire [20].

\subsection{Ascorbic acid, total carotenoids and antioxidant capacity}

For the determination of ascorbic acid contents, $5 \mathrm{~g}$ pulp tissues of plum fruit were homogenized with $20 \mathrm{~mL}$ metaphosphoric acid solution (6\%), $0.18 \%$ disodium salt of ethylene diamine tetra-acetic acid using pestle and mortar in white quartz sand. After centrifugation at $3186 \times g$ for $10 \mathrm{~min}, 400 \mu \mathrm{L}$ supernatant was reacted with $200 \mu \mathrm{L}$ metaphosphoric acid (3\%), $1.4 \mathrm{~mL}$ distilled water, and $200 \mu \mathrm{L}$ Folin's reagent $[5 \mathrm{~mL}$ distilled water: $1 \mathrm{~mL}$ Folin's reagent $(\mathrm{v} / \mathrm{v})]$ and ascorbic acid contents $\left[\mathrm{mg} 100 \mathrm{~g}^{-1}\right.$ fresh weight (FW)] were estimated as outlined earlier by Khan and Singh [21]. Fruit pulp tissues $(2 \mathrm{~g})$ were homogenized with $0.05 \mathrm{~g}$ magnesium carbonate, $20 \mathrm{~mL}$ acetone: $n$-hexane $[75: 60(\mathrm{v} / \mathrm{v})]$ in white quartz sand using pestle and mortar. Contents centrifuged at $3,186 \times g$ for 20 min at $4{ }^{\circ} \mathrm{C}$ were washed with $20 \mathrm{~mL} \mathrm{NaCl}(10 \%)$ and $20 \mathrm{~mL}$ of deionised water. Absorbance of washed extract was noted at $436 \mathrm{~nm}$ on a UV-visible spectrophotometer (model 6405; Jenway Ltd). Total carotenoids were calculated against the standard curve of $\beta$-carotene, and expressed as $\mathrm{mg}$ $100 \mathrm{~g}^{-1} \mathrm{FW}$ [18]. For determination of total antioxidants, pulp tissues $(5 \mathrm{~g})$ were homogenized with $10 \mathrm{~mL}$ extraction buffer ( $2 \mathrm{mmol} \mathrm{L}^{-1} \mathrm{NaF}$ and $200 \mathrm{~mL}$ distilled water) in white quartz sand using pestle and mortar. Following homogenization, contents were centrifuged at $1,000 \times g$ for $15 \mathrm{~min}$ and $50 \mu \mathrm{L}$ supernatant was reacted with $950 \mu \mathrm{L}$ of the working DPPH solution. Antioxidant activity was measured after $15 \mathrm{~min}$ as decrease in the absorbance at $515 \mathrm{~nm}$ on a UV-visible spectrophotometer (model 6405; Jenway Ltd) and was expressed as $\mu$ mol Trolox $100 \mathrm{~g}^{-1} \mathrm{FW}[22]$.

\subsection{Statistical analyses}

The experimental data were analyzed by using ANOVA with Genstat release 13.1 (Rothamsted, UK). Least significant differences (LSD) between the cultivars were estimated using significance $\mathrm{F}$ test $(P \leqslant 0.05)$.

\section{Results and discussion}

\subsection{Fruit growth and development}

All the Japanese plum cultivars exhibited double sigmoid growth pattern for fruit growth and development (figure 1).

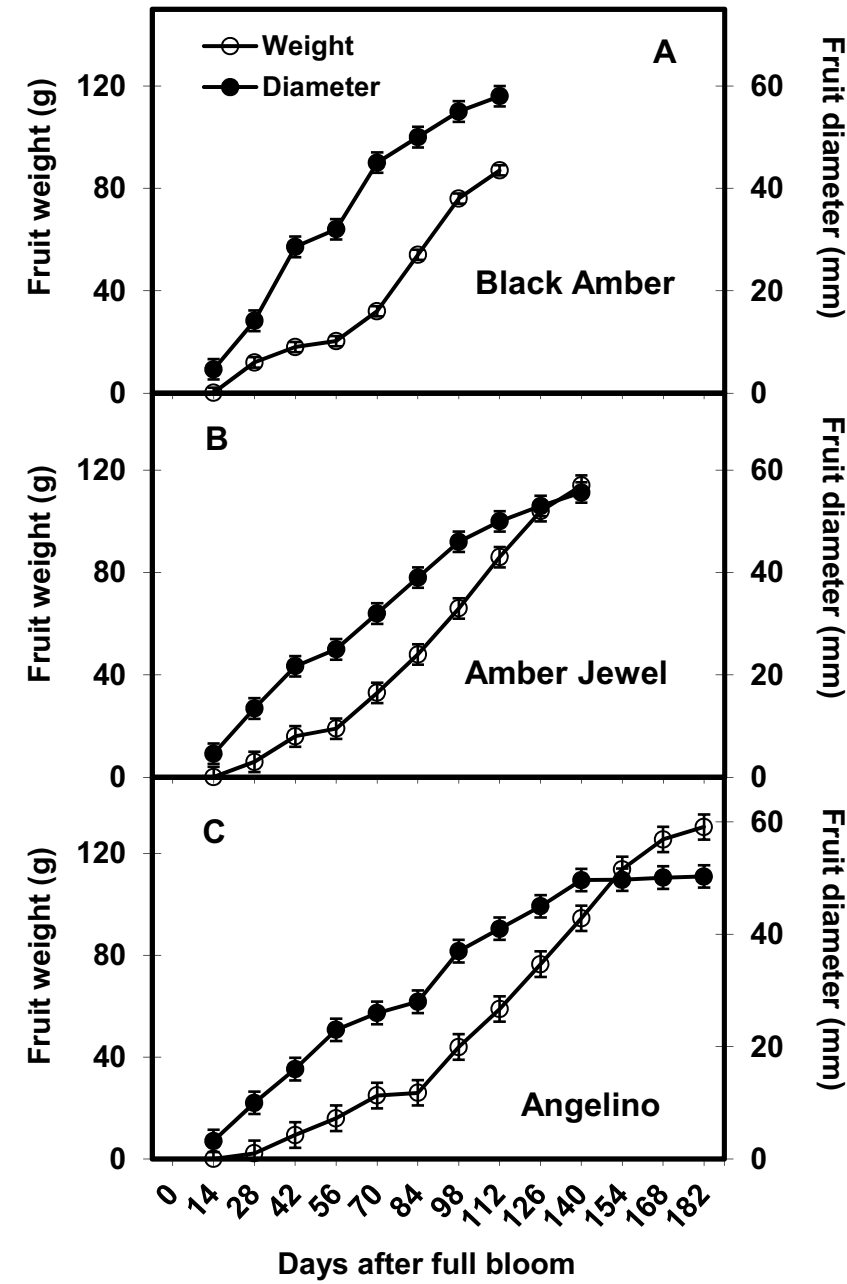

Figure 1. Changes in the fruit weight and diameter of 'Black Amber' [A], 'Amber Jewel' [B], and 'Angelino' [C] Japanese plum during fruit growth and development. Vertical bars represent standard errors of means ( $n=3$; three replications, 10 fruits per replication). LSD $(P \leqslant 0.05)$ for 'Black Amber' fruit: weight, 3.29; diameter, 2.15; for 'Amber Jewel' fruit: weight, 4.31; diameter, 3.65; for 'Angelino' fruit: weight, 5.74; diameter, 4.52 .

On absolute growth basis (increase per day), the fruit growth clearly showed three separate physiological phases (figure 2). The BA and AJ Japanese plum cultivars showed a period of rapid fruit growth up to 44 days after full bloom (DAFB) (Phase-I). Both cultivars exhibited a period for stone hardening (Phase-II) up to 58 DAFB. Duration of last phase of fruit growth and development for AJ and BA fruit was 98 days and 56 days, respectively. Figures 1 and 2 revealed that duration and distribution of these three phases of growth was different in late-season maturing AG Japanese plum, as compared with early- and mid-season maturing Japanese plum cultivars. The AG fruit exhibited a sharp rise in fruit weight and diameter up to 72 DAFB. From 72 to 86 DAFB these fruits showed a period of stone hardening. The duration of Phase-III for ' $\mathrm{AG}$ ' fruit was 64 days and 12 days more as compared with BA and AJ fruits, respectively. A similar double sigmoid pattern of fruit growth has also been observed by Zuzunaga et al. [5] 


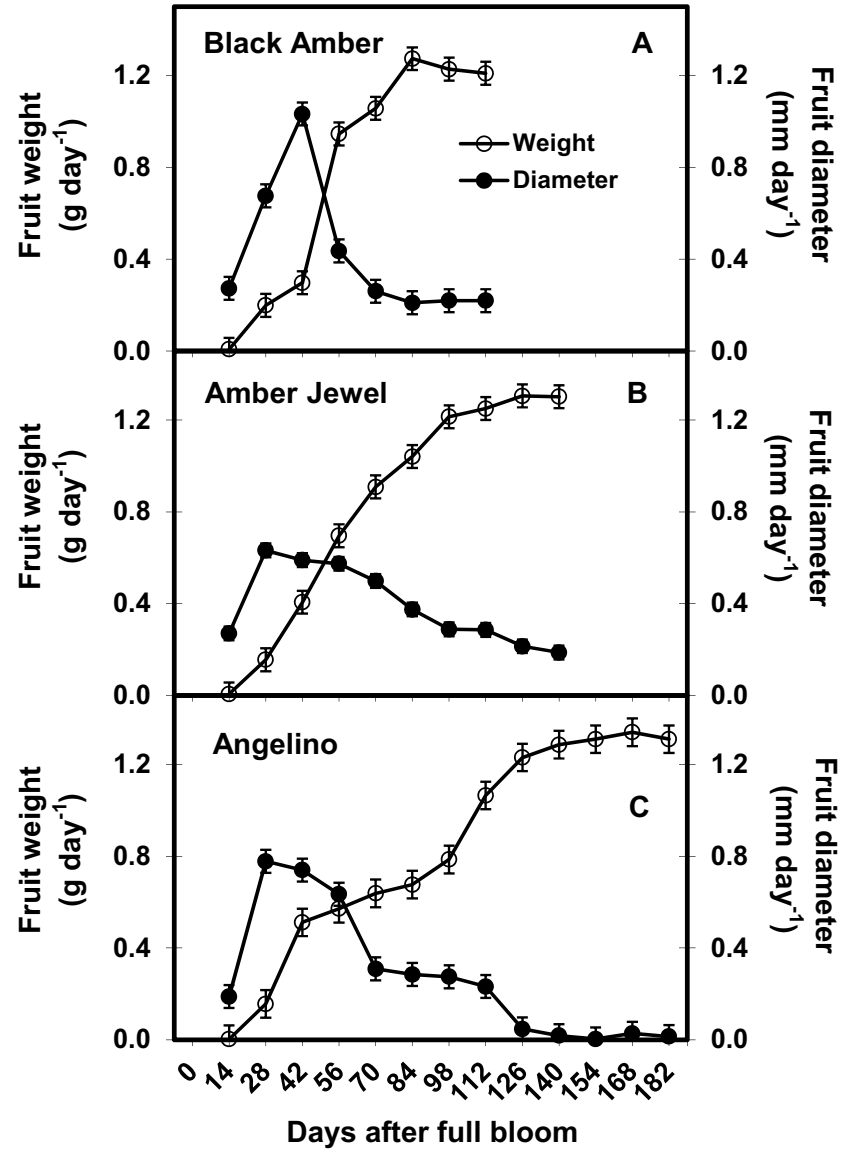

Figure 2. Changes in the absolute growth rate: fruit weight and diameter of 'Black Amber' [A], 'Amber Jewel' [B], and 'Angelino' [C] Japanese plum during fruit growth and development. Vertical bars represent standard errors of means ( $n=3$; three replications, 10 fruits per replication). LSD $(P \leqslant 0.05)$ for 'Black Amber' fruit: weight, 0.59; diameter, 0.25; for 'Amber Jewel' fruit: weight, 0.62; diameter, 0.36; for 'Angelino' fruit: weight, 0.83; diameter, 0.39 .

in 'Santa Rosa' and 'Golden Japan' Japanese plum. Stone fruits also possessed varying levels of plant growth substance during these phases of fruit growth, such as in apricot maximum plant growth substances were present in endocarp during Phase-I, growing embryo and endosperm during Phase-II and mesocarp and epicarp during phase-III [23].

All the three studied cultivars showed a gradual increase in pulp dry weight (\%) after stone hardening (Phase-II) up to harvest (figure 3A). However, AG fruit exhibited a prompt increase in skin dry weight (\%) from 28 DASH and at harvest these fruit showed 4.5 -fold higher skin dry weight (\%), as compared with AJ and BA fruits (figure $3 B$ ). The highest increase in seed dry weight (\%) was recorded in AJ fruit, which was 1.2- and 2.6-fold higher than BA and AG fruits respectively (figure $3 C$ ). After stone hardening all cultivars exhibited a sharp decline in fruit firmness and TA; however, SSC of all fruits increased with increase in DASH (figure 4). The highest SSC in AG fruit at harvest may be due to a long duration of Phase-III during fruit development compared to AJ and BA fruits (figure 3).

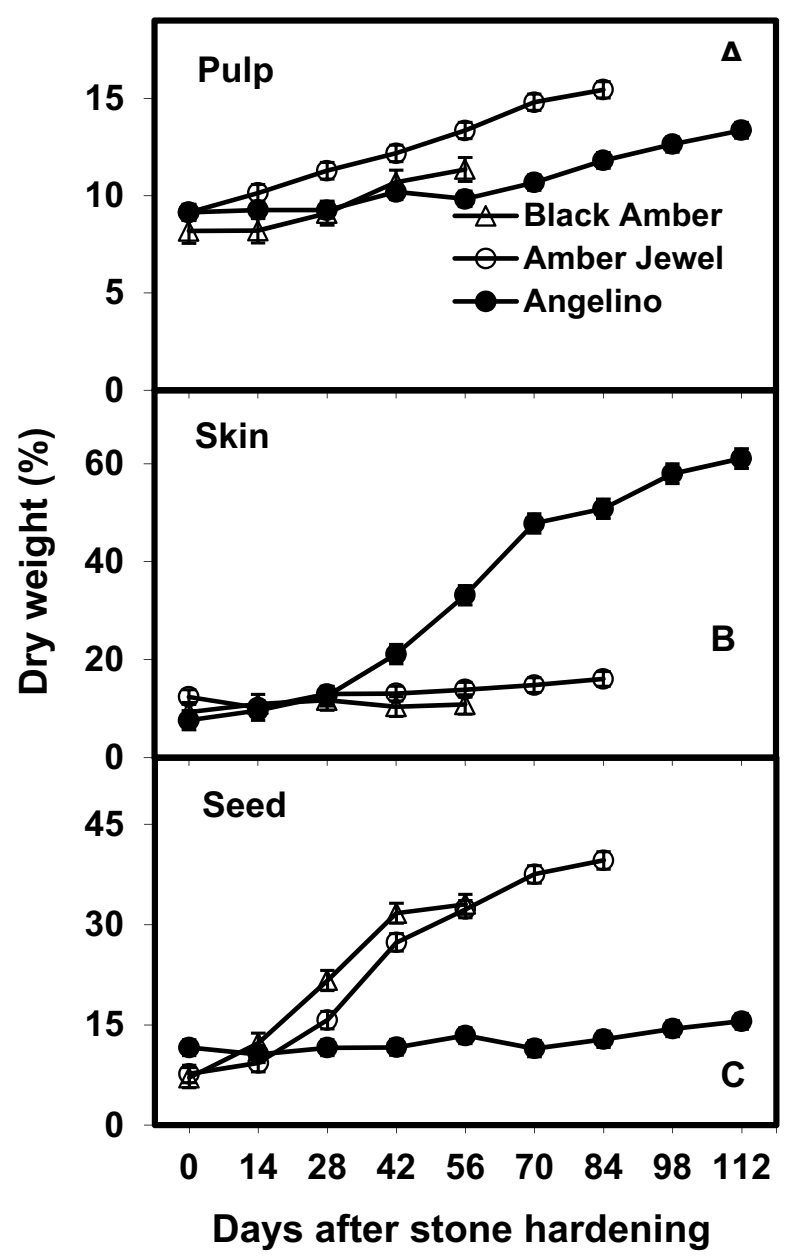

Figure 3. Changes in the dry weight percentage of fruit pulp (A), skin (B), and seed (C) tissues of 'Black Amber', 'Amber Jewel', and 'Angelino' Japanese plum during days after stone hardening. Vertical bars represent standard errors of means $(n=3$; three replications, 15 fruits per replication). LSD $(P \leqslant 0.05)$ for pulp dry weight: 'Black Amber', 1.38; 'Amber Jewel', 1.92; 'Angelino', 0.37. LSD $(P \leqslant 0.05)$ for skin dry weight: 'Black Amber', 0.81; 'Amber Jewel', 2.81; 'Angelino', 0.9 . LSD $(P \leqslant 0.05)$ for seed dry weight: 'Black Amber', 1.18; 'Amber Jewel', 0.84; 'Angelino', 0.99.

\subsection{Fruit ripening}

\subsubsection{Respiration rate and ethylene production}

'Black Amber' fruit exhibited their respiratory climacteric 3 and 5 days earlier (on day-4 of fruit ripening) and $\sim 4$ and 2-fold higher, as compared with AG and AJ fruits, respectively (figure 5A). Similarly, during fruit ripening, BA fruit showed their climacteric ethylene peak on day-5 of fruit ripening 4-fold higher than AJ fruit (figure 5B). However, during fruit ripening AG fruit did not exhibit any climacteric rise in ethylene production (figure $5 B$ ). On the basis of respiration rate and ethylene production during fruit ripening it is revealed that BA showed climacteric fruit ripening; whereas, $\mathrm{AJ}$ and $\mathrm{AG}$ exhibited suppressed climacteric ripening pattern [5, 23-25]. 


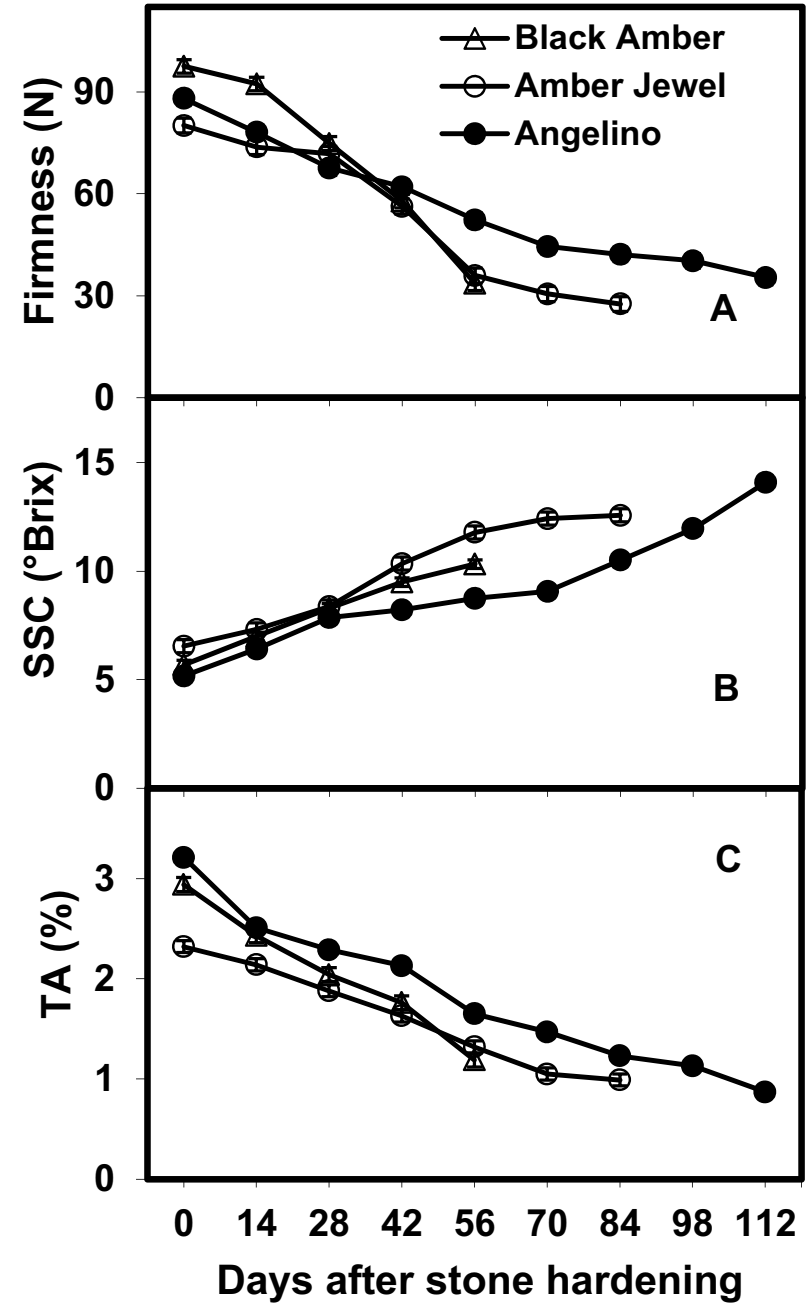

Figure 4. Changes in fruit firmness [A], soluble solids (SSC [B]), and titratable acidity (TA [C]) of 'Black Amber', 'Amber Jewel' and 'Angelino' Japanese plum during days after stone hardening. Vertical bars represent standard errors of means $(n=3$; three replications, 15 fruits per replication for fruit firmness). LSD $(P \leqslant 0.05)$ for fruit firmness: 'Black Amber', 2.01; 'Amber Jewel', 0.4; 'Angelino', 0.098. LSD $(P \leqslant 0.05)$ for SSC: 'Black Amber', 2.98; 'Amber Jewel', 0.54; ‘Angelino', 0.59. LSD $(P \leqslant 0.05)$ for TA: 'Black Amber', 0.14; 'Amber Jewel', 0.05; 'Angelino', 0.99.

The onset of ethylene production in climacteric fruit has been reported to hasten the fruit ripening and physico-chemical changes associated with fruit ripening $[26,27]$.

\subsubsection{Activities of ACS and ACO enzymes, and ACC content}

During first 5 days of fruit ripening all plum cultivars did not exhibit any change in the activity of ACS enzymes. Later on BA fruits exhibited a sharp rise in the activity of ACS enzyme and showed the highest ACS activity (6 pmol ACC mg protein ${ }^{-1} \mathrm{~h}^{-1}$ ) on day-7 of fruit ripening and about 7-fold and 2.4-fold higher than AJ and AG fruits, respectively

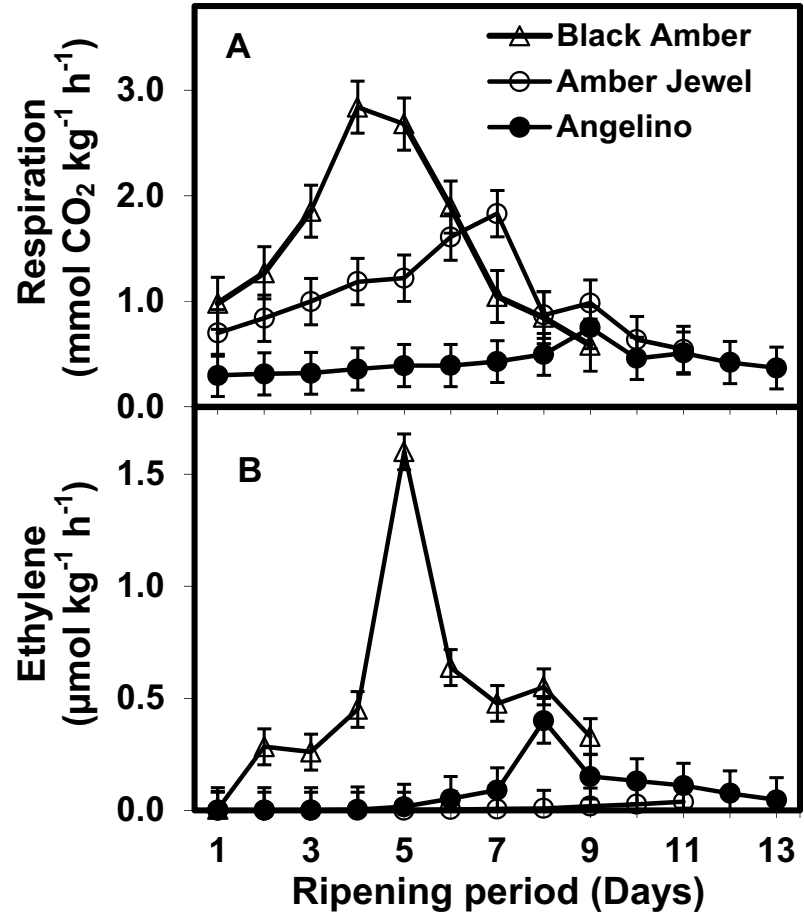

Figure 5. Changes in the respiration rate $[\mathrm{A}]$, and ethylene production [B] during fruit ripening of 'Black Amber', 'Amber Jewel' and 'Angelino' Japanese plum ( $n=3$; three replications). Vertical bars represent standard errors of means. LSD $(P \leqslant 0.05)$ for respiration rate: 'Black Amber', 1.03; 'Amber Jewel', 0.32; 'Angelino', 0.12. LSD $(P \leqslant 0.05)$ for ethylene production: 'Black Amber', 0.16; 'Amber Jewel', 0.01; 'Angelino', 0.02 .

(figure 6A). A similar trend in the activities of ACO enzymes and ACC contents was recorded during fruit ripening of all three plum cvs. On day-7 of fruit ripening, BA fruit exhibited 2.3- and 1.8-fold higher ACO activity and 3.5- and 2.3fold higher ACC contents than recorded in AG and AJ fruits, respectively (figure $6 B-C$ ). Similarly, some plum cultivars have been classified as climacteric e.g. 'Pioneer', 'Sapphire', 'Gulferby', 'Beauty', 'Santa Rosa', 'Black Star' and 'Black Diamond' with a very sharp rise in ethylene production and respiration rates, and others like 'Shiro' and 'Ruby Red', 'Songold' and 'Golden Japan' without any rapid increase in ethylene production and respiration rates, and are characterised as suppressed climacteric $[8,28-30]$. In the present study, the increase in ethylene production in climacteric cultivars was also accompanied by higher ACS activity that indicated an increase of ACC level as well as ACO activity as has been observed in some other climacteric fruits $[5,26]$. On the other hand, in suppressed climacteric plum the reduction in ethylene production may be ascribed to low ACS activity during fruit ripening. In AG fruit the complete reduction in ethylene production might be due to reduced activities of $\mathrm{ACO}$ and ACS enzymes and consequently ACC contents ( $f i g$ ure 6), as in our earlier experiments the exogenous application of 1-MCP and putrescine (ethylene inhibitors) have been reported to suppress the activities of ACS and ACO enzymes in Japanese plum [17,31]. 


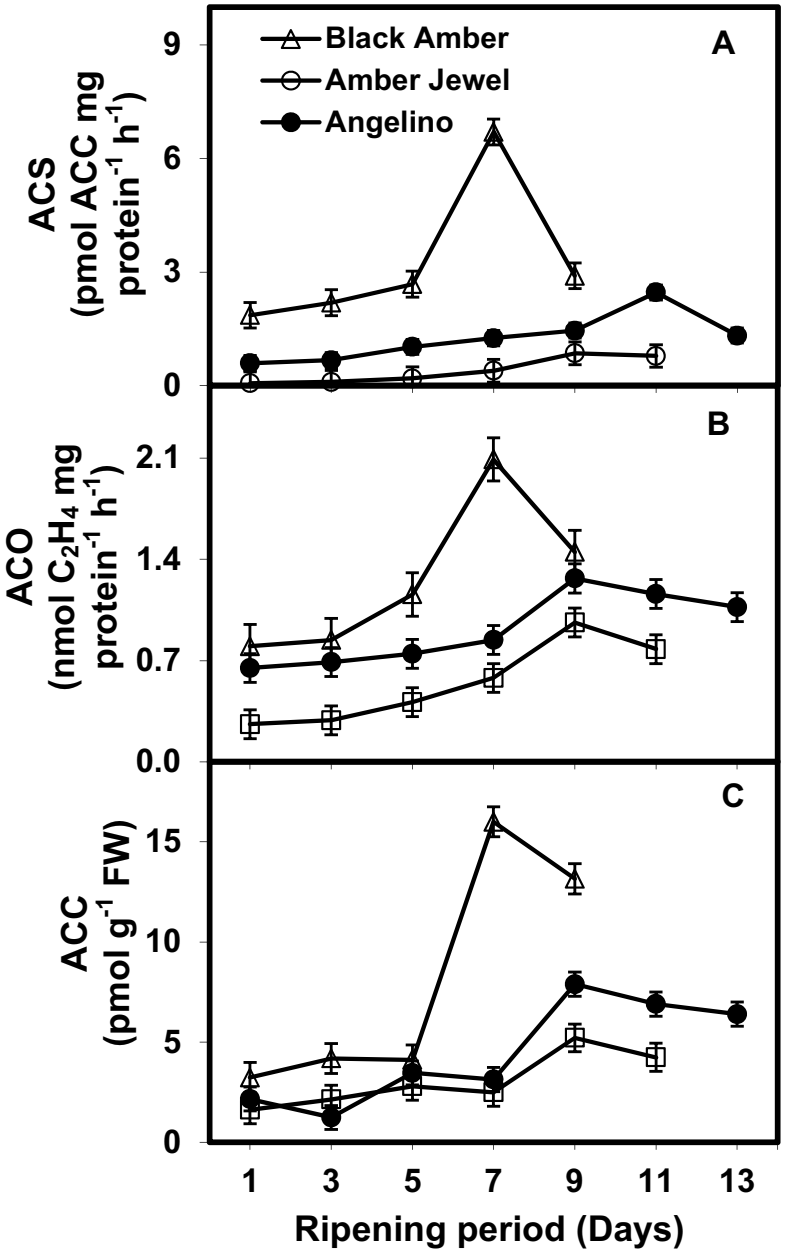

Figure 6. Changes in the activities of ACS [A], ACO [B] enzymes, and ACC content $[\mathrm{C}]$ during fruit ripening of 'Black Amber', 'Amber Jewel' and 'Angelino' Japanese plum ( $n=3$; three replications). Vertical bars represent standard errors of means. LSD $(P \leqslant 0.05)$ for fruit ACS: 'Black Amber', 1.12; 'Amber Jewel', 0.26; 'Angelino', 0.42. LSD $(P \leqslant 0.05)$ for ACO: 'Black Amber', 0.61; 'Amber Jewel', 0.11; 'Angelino', 0.18. LSD $(P \leqslant 0.05)$ for ACC: 'Black Amber', 2.44; 'Amber Jewel', 1.36; 'Angelino', 1.62.

\subsubsection{Fruit firmness}

On day-1 of fruit ripening the BA and AG fruits exhibited about 1.3-fold higher fruit firmness, as compared with AJ fruit (figure 7). During fruit ripening all plum cultivars showed a rapid increase in fruit softening. However, at ripe stage AJ and BA fruits exhibited the highest fruit softening in contrast to AG fruit. A higher rate of fruit softening accompanied with a higher rate of ethylene biosynthesis in BA fruit showed that ethylene production triggered the activities of cell-wall hydrolysis enzymes involved in the rapid softening of plum fruits. In earlier studies we reported that exogenous treatment of plum fruit with ethylene inhibitors reduced the fruit softening with suppressed activities of fruit softening enzymes (exo-polygalacturonase, endo-polygalacturonase pectin esterase and endo-1,4- $\beta$-D-glucanase) in some Japanese plum fruit $[17,21,32]$. Ethylene could also be the hormone responsible for the initiation of physico-chemical changes

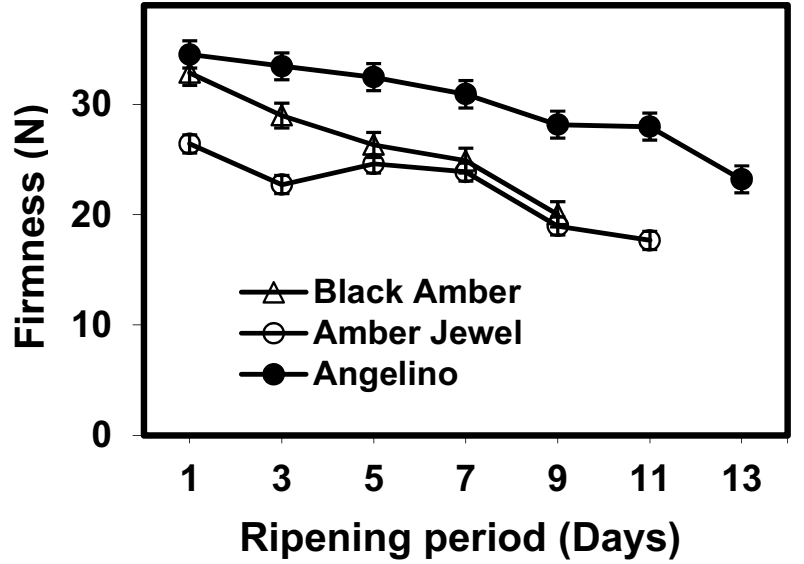

Figure 7. Changes in the fruit firmness during fruit ripening of 'Black Amber', 'Amber Jewel' and 'Angelino' Japanese plum $(n=24$; three replications, eight fruit per replication). Vertical bars represent SE of means. LSD $(P \leqslant 0.05)$ for fruit firmness: 'Black Amber', 2.62; 'Amber Jewel', 2.59; 'Angelino', 3.1.

associated with plum fruit ripening, as observed in other climacteric fruits, such as peach [33], melon [34], and tomato [35].

\subsubsection{Soluble solid content (SSC), titratable acidity (TA) and SSC:TA ratio}

During plum fruit ripening no significant changes in SSC and SSC:TA ratio were observed in all cultivars. However, at ripe stage $\mathrm{SSC}$ and $\mathrm{SSC}$ :TA ratio of $\mathrm{AG}$ fruit were higher than other cultivars (figure $8 \mathrm{~A}$ and $8 \mathrm{C}$ ). At harvest, BA fruit showed the highest TA $(1.32 \%)$ compared to AJ (0.98\%) and AG $(0.81 \%)$ fruits and during fruit ripening TA decreased with an increase in ripening period (figure $8 B$ ). During fruit ripening in suppressed climacteric fruit the changes in the SSC, TA and SSC:TA ratio occurred more slowly as compared with climacteric fruit. These results indicate that the postharvest ripening would be different for both types of ripening patterns, being faster in BA and AJ than AG fruits. Similar results have been reported in Japanese plum by Zuzunaga et al. [5], in which non-climacteric cultivars exhibited slower fruit ripening with greater longevity than climacteric plum.

\subsubsection{Fruit color}

A sharp decline in chromaticity value $L^{*}$ was observed in AJ fruit during fruit ripening as compared with $\mathrm{BA}$ and $\mathrm{AG}$ fruits (figure 9A). Similarly, BA and AG fruits did not show any significant change in chromaticity values $a^{*}, b^{*}$, chroma value $\left(C^{*}\right)$ and hue angle $\left(h^{\circ}\right)$ during fruit ripening as compared with AJ fruit (figure 9B, 9C). The rate of decrease in chromaticity value $a^{*}$ and $b^{*}$ in $\mathrm{AJ}$ fruit was more rapid after day-9 of fruit ripening. The $C^{*}$ and $h^{\circ}$ did not change in BA and AG fruits during fruit ripening whereas $\mathrm{AJ}$ fruit showed a decrease in $C^{*}$ value at the ripe stage and $C^{*}$ value was 32.3 -fold less than on 


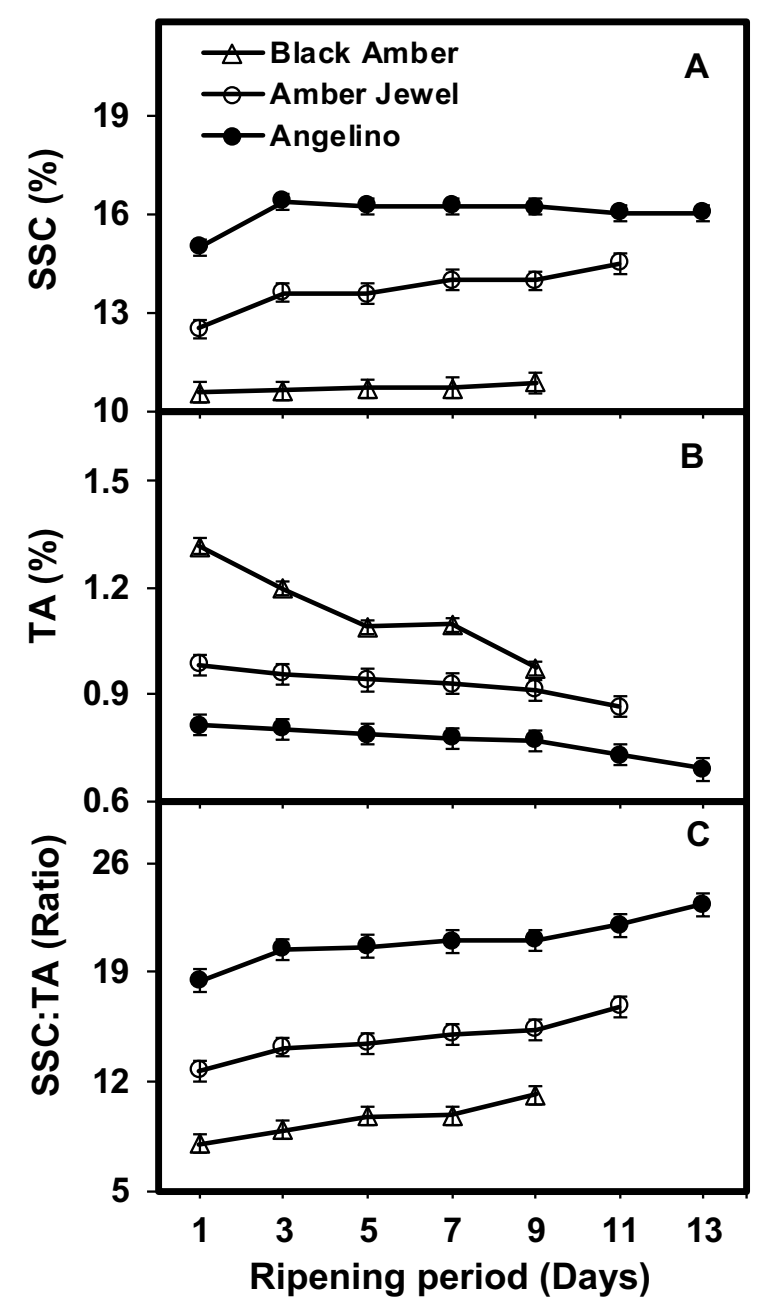

Figure 8. Changes in the soluble solid contents (SSC [A]), titratable acidity (TA $[\mathrm{B}]$ ), and the SCC:TA ratio $[\mathrm{C}]$ during fruit ripening of 'Black Amber', 'Amber Jewel' and 'Angelino' Japanese plum fruit ( $n=3$; three replications). Vertical bars represent SE of means. LSD $(P \leqslant 0.05)$ for fruit SSC: 'Black Amber', NS; 'Amber Jewel', 0.19; 'Angelino', 0.1. LSD $(P \leqslant 0.05)$ for TA: 'Black Amber', 0.01; 'Amber Jewel', 0.02; 'Angelino', 0.01. LSD $(P \leqslant 0.05)$ for SCC:TA ratio: 'Black Amber', 0.19; 'Amber Jewel', 0.29; 'Angelino', 0.33. NS = not significant.

day-1 of fruit ripening. A similar trend in change in $h^{\circ}$ was observed where AJ fruit exhibited a decrease in $h^{\circ}$ with increase in fruit ripening period. The lower values of color parameters (chromaticity values $L^{*}, a^{*}, b^{*}, C^{*}$ and $h^{\circ}$ ) and no significant changes in these values in BA and AG fruits were probably due to their dark surface color at harvest, as compared with AJ fruit. The AJ fruit exhibited a gradual decrease in color parameters during fruit ripening, as compared with BA and AG fruits (figures 9, 10).

\subsubsection{Ascorbic acid, carotenoids and antioxidant activity}

All plum cultivars exhibited an increase in the level of ascorbic acid during fruit ripening (figure 11A). The highest level of ascorbic acid was determined in AG (24 mg

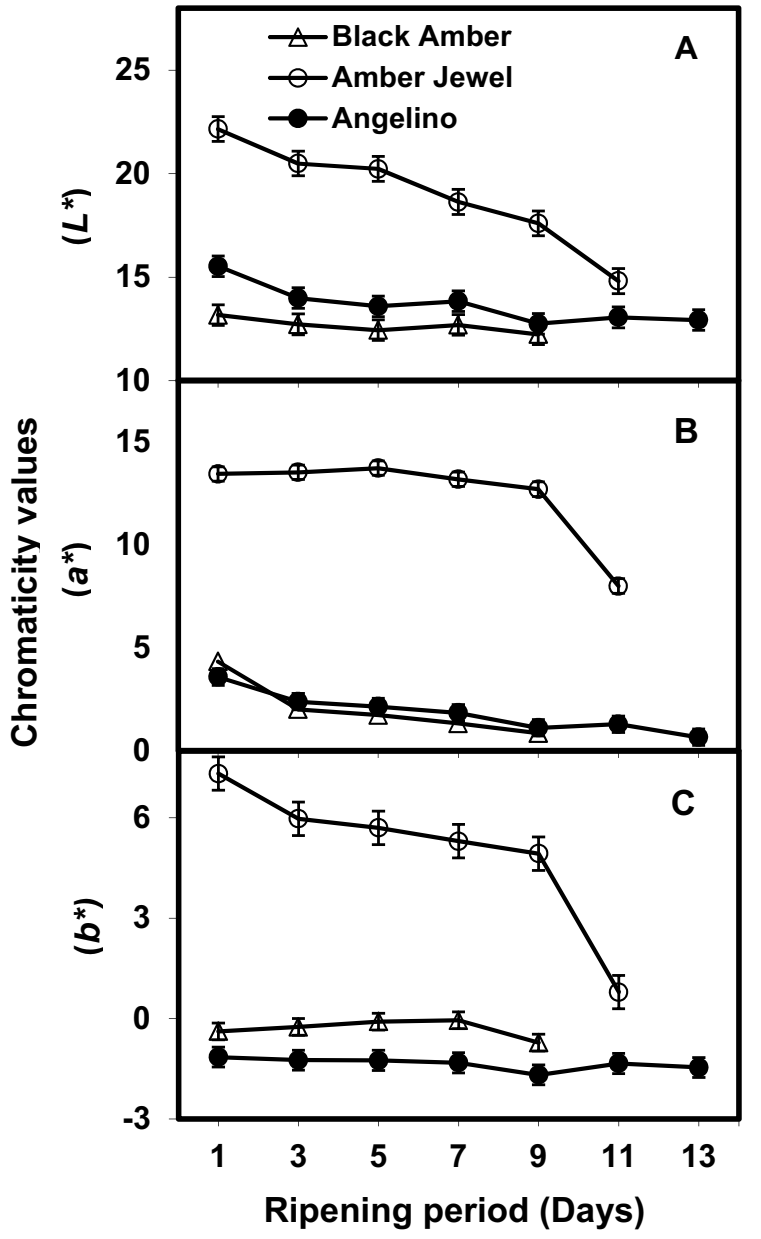

Figure 9. Changes in the chromaticity values $L^{*}[\mathrm{~A}], a^{*}[\mathrm{~B}]$, and $b^{*}$ $[C]$ during fruit ripening of 'Black Amber', 'Amber Jewel' and 'Angelino' Japanese plum fruit ( $n=3$; three replications). Vertical bars represent SE of means. LSD $(P \leqslant 0.05)$ for fruit $\mathrm{L}^{*}$ : 'Black Amber', NS; 'Amber Jewel', 1.19; 'Angelino', 0.64. LSD $(P \leqslant 0.05)$ for a*: 'Black Amber', 0.27; 'Amber Jewel', 1.04; 'Angelino', 0.43. LSD $(P \leqslant 0.05)$ for $\mathrm{b}^{*}$ : 'Black Amber', NS; 'Amber Jewel', 1.65; 'Angelino', NS.

$\left.100 \mathrm{~g}^{-1} \mathrm{FW}\right)$, followed by BA (22 mg $\left.100 \mathrm{~g}^{-1} \mathrm{FW}\right)$ and AJ (18 $\mathrm{mg} 100 \mathrm{~g}^{-1}$ ) fruits. Similarly, in earlier studies differences in ascorbic acid content have also been observed in some Japanese and European plum cultivars [36]. During the first 5 days of fruit ripening $\mathrm{AJ}$ and $\mathrm{AG}$ cultivars did not exhibit any change in the level of total carotenoids. However, the level of total carotenoids was highest in BA on day-5 of fruit ripening and later on in this fruit it declined with advancement of ripening period. In contrast to $\mathrm{BA}, \mathrm{AJ}$ fruits exhibited a sharp rise in the level of total carotenoids on day- 6 of fruit ripening and exhibited the highest level of total carotenoid on day- 9 of fruit ripening about 1.4- and 1.8-fold higher than highest values of $\mathrm{BA}$ and $\mathrm{AG}$ fruits, respectively (figure $11 \mathrm{~B}$ ).

The level of total antioxidant activity in all Japanese plum fruits increased during the fruit ripening period and reached their maximum level and then decreased during later stages of fruit ripening (figure $11 \mathrm{C}$ ). The highest levels of total antioxidant activity were observed in BA fruit $(215 \mu \mathrm{mol}$ 


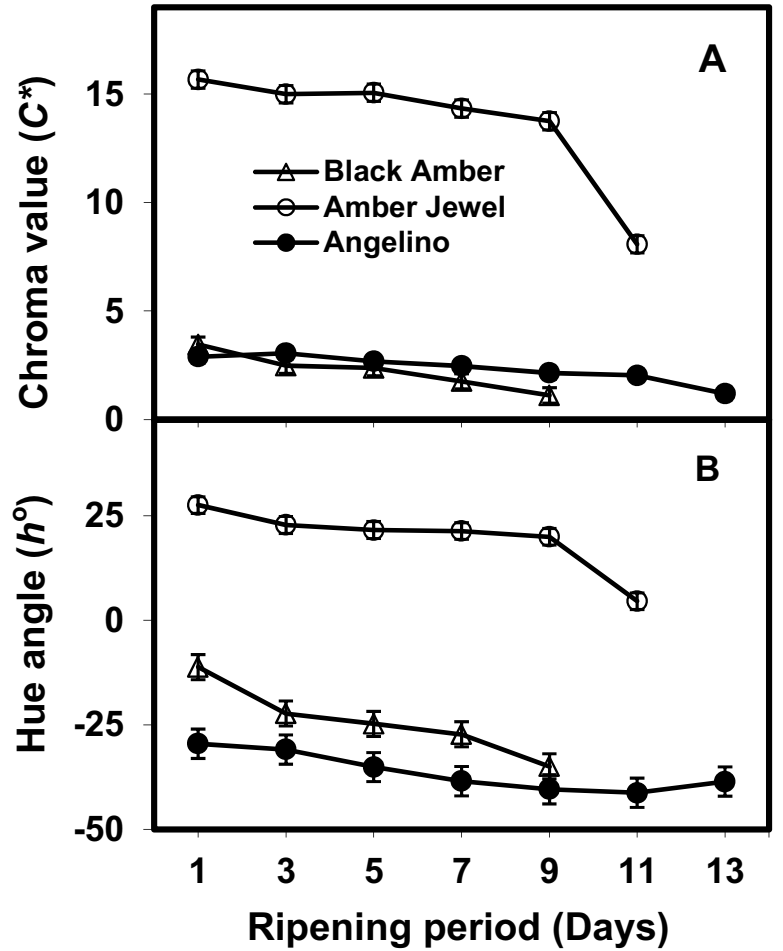

Figure 10. Changes in the chroma value $C^{*}[\mathrm{~A}]$, and hue angle $h^{\circ}$ [B] during fruit ripening of Amber', 'Amber Jewel' and 'Angelino' Japanese plum fruit ( $n=3$; three replications). Vertical bars represent SE of means. LSD $(P \leqslant 0.05)$ for fruit chroma value: 'Black Amber', 0.29; 'Amber Jewel', 1.28; 'Angelino', 0.35. LSD $(P \leqslant 0.05)$ for hue angle: 'Black Amber', 5.35; 'Amber Jewel', 5.31; 'Angelino', NS.

Trolox $100 \mathrm{~g}^{-1} \mathrm{FW}$ ) on day-7 of fruit ripening. Whilst, AJ and AG fruits exhibited their highest level of total antioxidant activity (208 $\mu$ mol Trolox $\left.100 \mathrm{~g}^{-1} \mathrm{FW}\right)$ on day-9 of fruit ripening. No consistent trend has been found between individual and total antioxidant activities in all Japanese plum cultivars. The higher level of total carotenoids in AJ fruit could be due to some antioxidant compounds other than ascorbic acid and total carotenoids. It has been reported that the phytochemicals present in various fruits which are responsible for antioxidant activities are mainly due to the presence of phenolic acids, flavonoid compounds, and vitamins [37]. The highest levels of ascorbic acid, total carotenoids, and total antioxidant activity in Japanese plum fruit depend upon the cultivar and stage of fruit ripening. The difference in the level of antioxidant activity in the different cultivars is also related to duration of fruit growth and development before harvest [38].

\section{Conclusion}

The duration of Phase-III of fruit growth in early-season ('Black Amber', BA) maturing cultivar is short as compared with mid- ('Amber Jewel', AJ) or late-season ('Angelino', AG) maturing cultivars. The AG Japanese plum fruit showed a suppressed climacteric ripening pattern; whereas, BA and AJ exhibited climacteric fruit ripening. In Japanese plum

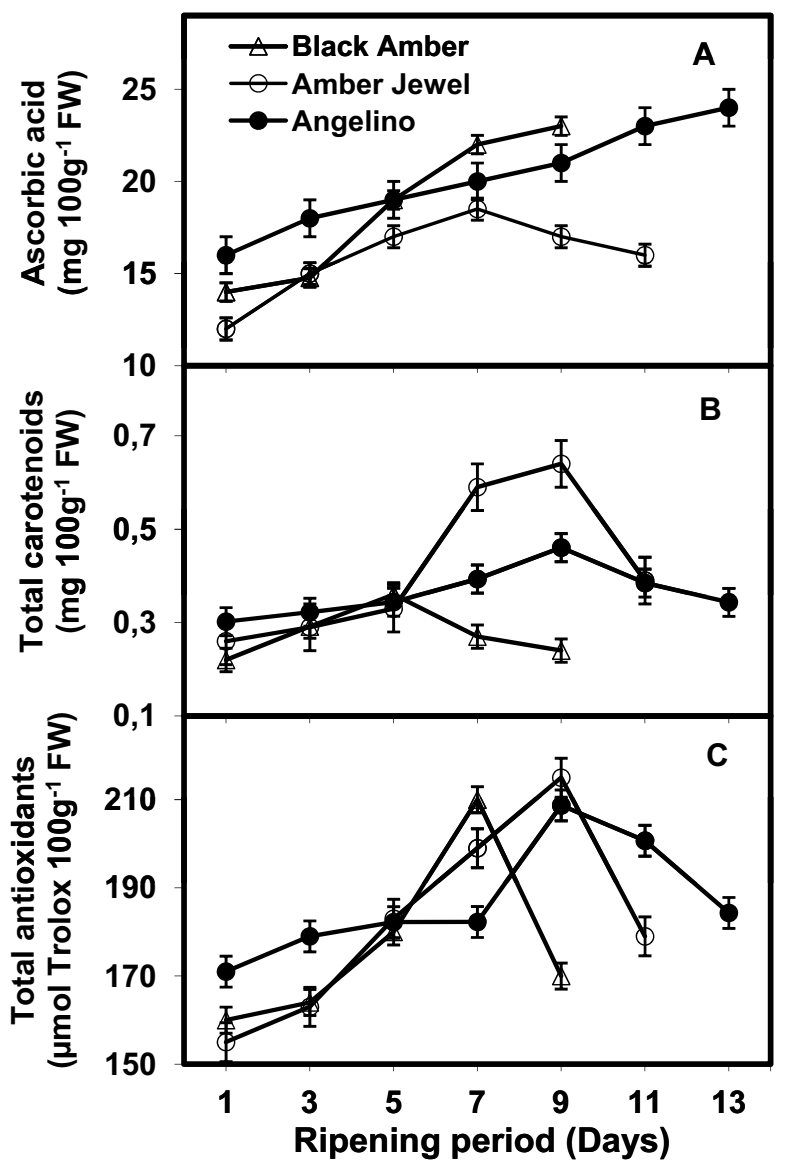

Figure 11. Changes in the levels of ascorbic acid $[\mathrm{A}]$, total carotenoids [B], and total antioxidants $[\mathrm{C}]$ during fruit ripening of 'Black Amber', 'Amber Jewel' and 'Angelino' Japanese plum fruit ( $n=3$; three replications). Vertical bars represent SE of means. LSD $(P \leqslant 0.05)$ for fruit Ascorbic acid: 'Black Amber', 0.25; 'Amber Jewel', 0.31; 'Angelino', 0.28. LSD $(P \leqslant 0.05)$ for total carotenoids: 'Black Amber', 0.01; 'Amber Jewel', 0.03; 'Angelino', 0.02. LSD $(P \leqslant 0.05)$ for total antioxidants: 'Black Amber', 6.98; 'Amber Jewel', 10.3; 'Angelino', 8.91 .

fruit, physico-chemical changes during fruit ripening vary with cultivar and are associated with a level of endogenous ethylene production. Differently maturing Japanese plum cultivars exhibited varying levels of individual and total antioxidant activities of their fruit at fully ripe stage.

\section{References}

[1] FAOSTAT data, Retrieved 28 December 2007, from http:// faostat.fao.org/. (2007).

[2] Australian Bureau of Statistics, Retrieved on 29 December 2005 from http://www.abs.gov.au/. (2005).

[3] Ward G., Melvin Carter E., Pasqual G., Stone fruit from Western Australia: at a glance, Department of Agriculture Western Australia. Bulletin, 4397, Agriculture Western Australia, South Perth, 2000. 
[4] Tromp J., Wertheim S.J., Fruit growth and development, in: Tromp J., Webster A.D., Wertheim S.J. (Eds.), Fundamentals of temperate zone tree fruit production, Backhuys Publishers, Leiden, 2005.

[5] Zuzunaga M., Serrano M., Martinez-Romero D., Valero D., Riquelme F., Comparative study of two plum (Prunus salicina Lindl.) cultivars during growth and ripening, Food Sci. Technol. Int. 7 (2001) 123-130.

[6] LaRue J.H., Johnson R.S., Peaches, plums and nectarines: Growing and handling for fresh market, Cooperative Extension, University of California, Division of Agriculture and Natural Resouces, Publication 3331, 1989.

[7] Salunkhe D.K., Kadam S.S. (Eds.), Handbook of fruit science and technology : Production, composition, storage, and processing, Marcel Dekker, New York, 1995.

[8] Abdi N., Hofford, P., McGlasson W., Mizrahi, Y., Ripening behaviour and responses to propylene in four cultivars of Japanese type plums, Postharvest Biol. Technol. 12 (1997) 21-34.

[9] Jason J.S., Chohan G.S., Maturity study in plum cv. Kala Amritsari under subtropical conditions, Prog. Hort. 14 (1982) 11.

[10] Cambrink M.B., Plums and Related Fruits, in: MaCre R., Robinson R.K., Sadler M.J. (Eds.), Encyclopedia of food science, food technology and nutrition, Academic Press, London, 1993.

[11] Westwood M.N., Temperate-zone pomology: Physiology and culture, Timber Press, Portland, Oregon, 1993.

[12] Bal J.S., Chohan G.S., Studies on the fruit maturity and quality of plum cv. Titron in Punjab, National symposium on temperate fruits held at Solan HPKVV, March, 1982, 57, 1982, pp. 15-18.

[13] Tormann H., Zyl H.J.V., Maturity standards for export plums, Deciduous Fruit Grow. 32 (1982) 22.

[14] Crisosto C.H., Stone fruit maturity indices: a descriptive review, Postharvest News Info. 5 (1994) 65-68.

[15] Giovannoni J., Molecular biology of fruit maturation and ripening, Ann. Rev. Plant Physiol. Mol. Biol. 52 (2001) 725-749.

[16] Kader A.A., Fruit maturity, ripening and quality relationships, Acta Hortic. 485 (1999) 203-208.

[17] Khan A.S., Singh Z., Pre-harvest application of putrescine influence Japanese plum fruit ripening and quality, Fruit Sci. Technol. Int. 16 (2010) 53-64.

[18] Khan A.S., Ahmed M.J., Singh Z., Increased ethylene biosynthesis elevates incidence of chilling injury in cold-stored 'Amber Jewel' Japanese plum (Prunus salicina Lindl.) during fruit ripening, Int. J. Food Sci. Technol. 46 (2011) 642-650.

[19] Bradford M.M., A rapid and sensitive method for the quantitation of microgram quantities of protein utilizing the principles of protein-dye binding, Anal. Biochem. 72 (1976) 248-254.

[20] McGuire R.G., Reporting of objective color measurements, HortScience 27 (1992) 254-255.

[21] Khan A.S., Singh Z., 1-Methylcyclopropene application and modified atmosphere packaging affect ethylene biosynthesis, fruit softening, and quality of 'Tegan Blue' japanese plum during cold storage, J. Am. Soc. Hort. Sci. 133 (2008) 290-299.

[22] Brand-Williams W., Cuvelier M.E., Berset C., Use of a free radical method to evaluate antioxidant activity. LebensmittelWissenschaft und-Technologie 28 (1995) 25-30.
[23] Baldicchi A., Farinelli D., Micheli M., Di Vaio C., Moscatello S., Battistelli A., Walker R.P., Famiani F., Analysis of seed growth, fruit growth and composition and phospoenolpyruvate carboxykinase (PEPCK) occurrence in apricot (Prunus armeniaca L.), Sci. Hortic. 186 (2015) 38-46.

[24] Khan A.S., Singh Z., Pre-harvest application of putrescine influence Japanese plum fruit ripening and quality, Fruit Sci. Technol. Int. 16 (2010) 53-64.

[25] Lelievre J.M., Latchè A., Jones B., Bouzayen M., Pech J.-C., Ethylene and fruit ripening, Physiol. Plant. 101 (1997) 727-739.

[26] Abdi N., McGlasson W.B., Holford P., Williams M., Mizrahi J., Responses of climacteric and suppressed-climacteric plums to treatment with propylene and 1-methylcyclopropene, Postharvest Biol. Technol. 14 (1998) 29-39.

[27] Amoros A., Zapata P., Pretel M.T., Botella M.A., Serrano M., Physico-chemical and physiological changes during fruit development and ripening of five loquat (Eriobotrya japonica Lindl.) cultivars, Food Sci. Technol. Int. 9 (2003) 43-51.

[28] Yang S.F., Oetiker J.J., Molecular biology of ethylene biosynthesis and its application in horticulture, J. Japn. Soc. Hort. Sci. 67 (1998) 1209-1214.

[29] Kruger L., Cook N., Holcroft D.M., Quality of Japanese plums as influenced by time of harvest and rate of ethylene production, Acta Hortic. 600 (2003) 453-456.

[30] Zuzunaga M., Rodriguez P., Derrano M., Riquelme F., Responses to ethylene treatments in two plum cultivars, Acta Hortic. 553 (2001) 179-180.

[31] Serrano M., Martinez-Romero D., Gillen F., Valero D., Effect of exogenous putrescine on improving shelf life of four plum cultivars, Postharvest Biol. Technol. 30 (2003) 259-271.

[32] Khan A.S., Singh Z., Abbasi N.A., Pre-storage putrescine application suppresses ethylene biosynthesis and retards fruit softening during low temperature storage in 'Angelino' Plum, Postharvest Biol. Technol. 46 (2007) 36-46.

[33] Martınez-Madrid M.C., Serrano M., Pretel M.T., MartinezReina G., Romojaro F., The ripening of Prunus persica fruits with a dominant flat allele, Food Sci. Technol. Int. 6 (2000) 399-405.

[34] Martınez-Madrid M.C., Martínez G., Pretel M.T., Serrano M., Romojaro F., Role of ethylene and abscisic acid in physicochemical modifications during melon ripening, J. Agri. Food Chem. 47 (1999) 5285-5290.

[35] Martınez-Madrid M.C., Serrano M., Riquelme F., Romojaro F., Polyamines, abscisic acid and ethylene production in tomato fruit, Phytochem. 43 (1996) 323-326.

[36] Gil M.I., Tomas-Barberan A.T., Hess-Pierce B., Kader A.A., Antioxidant capacities, phenolic compounds, carotenoids, and vitamin $\mathrm{C}$ contents of nectarine, peach, and plum cultivars from California, J. Agric. Food Chem. 50 (2002) 4976-4982.

[37] Vasantha Rupasinghe H.P., Jayasankar S., Lay W., Variation in total phenolics and antioxidant capacity among European plum genotypes, Sci. Hortic. 108 (2006) 243-246.

[38] Jooste M., Rohwer E.A., Kidd M., Huysamer M., Comparison of antioxidant levels and cell membrane composition during fruit development in two plum cultivars (Prunus salicina Lindl.) differing in chilling resistance, Sci. Hortic. 180 (2014) $176-189$ 